\title{
The influence of the magnetoplasma install on growth parameters of sunflower Helianthus annuus $\mathrm{L}$
}

\author{
(C) Daria V. Sergeeva, ${ }^{1+}$ and Pyotr P. Purygin ${ }^{2 *}$ \\ ${ }^{1}$ Department of Technology of Freight and Commercial Work, Stations and Nodes. Samara State University \\ of Communications. Freedom St., 2B. Samara, 443066. Russia. Phone: +7 (927) 602-65-96. \\ E-mail:dv.sergeeva@yandex.ru \\ ${ }^{2}$ Department of Organic Chemistry. Samara State University. Ak. Pavlova St., 1. Samara, 443011. \\ Russia. Phone: +7 (846) 334-54-59. E-mail: puryginpp2002@mail.ru
}

\begin{abstract}
*Supervising author; ${ }^{+}$Corresponding author
Keywords: magnetic plasma device $Y M P O-2$, magnetic field, pre-sowing treatment, sunflower ordinary, oil product, toxicity, Helianthus annuus L.
\end{abstract}

\begin{abstract}
The study assessed the impact of magnetic plasma installation $Y M P O-2$ on sunflower seeds treated with petroleum products of different concentrations $(0.5 \%, 0.9 \%, 2.9 \%, 4.7 \%)$. The plant generates a gradient magnetic field with variable induction from 50 to 300 GS and is equipped with a powerful source of UV radiation with a wave range of $248-340 \mathrm{~nm}$, which has a strong bactericidal effect, and the magnetic field is able to activate vital processes in seeds. The analyzed parameters of sunflower: seed germination (total and daily), growth energy and length of seedlings. The positive effect of the gradient magnetic field, ultraviolet radiation and ozone, created by a powerful magnetic inductor, was revealed due to the observation of sunflower growth parameters for 30 days. Under the influence of UMPO-2 increases the permeability of cell membranes, resulting in changes in the concentration of substances in plant cells, increases the rate of chemical reactions and increases water absorption of seeds. According to the results of the experiment, the stimulating effect of the magnetoplasmic installation on germination, growth energy and length of seedlings was noted not only on healthy sunflower seeds, but also on seeds treated with petroleum products in four different concentrations $(0.5 \%, 0.9 \%, 2.9 \%, 4.7 \%$ kerosene). When germinating seeds with the addition of kerosene to the substrate, the deterioration of agrochemical properties of the soil was noted, as a result, the growth of stems and other vegetative organs of sunflower was delayed. However, the seeds with added oil, treated with magnetic plasma installation $U M P O-2$, germinated together, the growth delay was noted slight. Also, after the impact of $U M P O-2$ on seeds not treated with petroleum products, positive dynamics of growth within 30 days, maximum germination and germination energy were revealed.
\end{abstract}

\section{References}

[1] M.M. Shashurin. Influence of presowing treatment of seeds of onion (Allium fistulosum L.) by a constant magnetic field on physiological and biochemical characteristics of its seedlings. Science and education. 2016. No.4. P.119-123 (russian)

[2] Device for pre-sowing seed treatment. RF patent 118161/13 Putko V.F., 2012. Bul. No. 20. 20.07.12.

[3] P.P. Purygin, D.A. Tsaplev, V.A. Purygin., Y.P. Zarubin, T.I. Vasilyeva. Study of the level of carotenoids, chlorophylls a and b in seedlings of common barley seeds (Hordeum vulgare) after pretreatment of seeds by a constant magnetic field and UV radiation in the presence of ozone. Butlerov Communications. 2015. Vol.42. No.5. P.23-25. DOI: 10.37952/ROI-jbc-01/15-42-5-23

[4] P.P. Purygin, A.D. Tsaplev, E.V. Tsapleva., Y.P. Zarubin. Determination of specific activity of peroxidase of barley (Hordeum vulgare) and common millet (Panicum miliaceum) when exposed to ozone and constant magnetic field. Butlerov Communications. 2013. Vol.35. No.9. P.90-93. ROI: jbc02/13-35-9-90

[5] D.V. Sergeeva, P.P. Purygin. Study of the influence of petroleum products on the growth parameters and development of the rhizome of sunflower seeds Helianthus annuus L.. Butlerov Communications. 2017. Vol.52. No.12. P.124-128. DOI: 10.37952/ROI-jbc-01/17-52-12-124

[6] T.A. Khripchenko, Yu.A. Kholopov. Fuel depots as objects of potential danger of emergency situations on railway transport. In the collection: Environmental safety of Russian regions and the risk of man-made accidents and disasters. A collection of articles of the XIV International Scientific and Practical Conference. Edited by Y. P. Perelygin. 2014. P.100-103. (russian) 
THE INFLUENCE OF THE MAGNETOPLASMA INSTALL ON GROWTH PARAMETERS OF SUNFLOWER... $72-76$

[7] S. Malakhov. Temporary methodological recommendations on soil contamination control. USSR State Committee for Hydrometeorology and Environmental Control. Institute of Experimental Meteorology, Moscow. 1984. 4p. (russian)

[8] I.V. Kazantsev. Pollution and methods for cleaning soils from oil products in railway transport. In the collection: Bioecological study of local lore: world, Russian and regional problems. Materials of the 3 rd All-Russian scientific and practical conference with international participation, dedicated to the 85th anniversary of the natural-geographical faculty of the PSSGA. 2014. P.28-33. (russian)

[9] I.N. Rusinova, V.V. Slyusarenko, A.V. Rusinov. The use of glauconite in the detoxification of soils contaminated with oil products. Technosphere Security: Science and Practice: Proceedings of the International Scientific and Practical Conference. Saratov, OOO KUBIK Publishing House. 2015. P.6062. (russian)

[10] D.A. Rusinov, Y.A. Kholopov. Methods for cleaning soils and soils contaminated with petroleum products in railway transport. In the collection: Innovations in environmental management and protection in emergency situations. Materials of the III International Scientific and Practical Conference. V.V. Slyusarenko (responsible editor). 2016. P.35-39. (russian)

[11] D.V. Sergeeva. Influence of oil products on germination and growth parameters of sunflower common Helianthus annuus L. Days of student science: materials XLIV scientific conference SSTU. Samara State Transport University. Issue 18. Samara: SSTU. 2017. P.144. (russian) 